Karagöz, B. (2018). Ortaokul 5. sınıf öğrencilerinin resimli çocuk kitaplarına ilişkin tepkileri üzerine bir inceleme. Ana Dili Eğitimi Dergisi, 6(4), 1198-1218.

$\begin{gathered}\text { Ana Dili Eğitimi Dergisi } \\ \text { Journal of MotherTongueEducation } \\ \text { www.anadiliegitimi.com }\end{gathered}$
Geliş/Received: 02.06 .2018 Kabul/Accepted: 18.10 .2018

\title{
Ortaokul 5. Sınıf Öğrencilerinin Resimli Çocuk Kitaplarına İlişkin Tepkileri Üzerine Bir İnceleme*
}

\author{
Beytullah KARAGÖZ*
}

\begin{abstract}
Öz
Edebiyat metinlerini anlama ve yorumlama uğraşında okurun rolü önemlidir. Okur, metnin çözümlenmesi ve anlamın yeniden üretilmesinde etkindir. Bu nedenle yazınsal okuma süreçlerinde okurun bilgi, beceri yönünden yetkin ve donanımlı olması gerekir. Okurun yetileri üzerine inşa edilen bu süreçte estetik alımlayıcı öngörüsü, bilinci, duyarlılığı ile anlama edimini gerçekleştirir. Bu çalışmada ortaokul beşinci sınıfta öğrenim gören öğrencilerin resimli çocuk kitaplarına yönelik yazııı görüşlerini okur-tepki kuramı açısından çözümlemek amaçlanmıştır. Araştırma nitel araştırma desenlerinden durum çalışması kullanılarak desenlenmiştir. Araştırmanın verileri Tokat il merkezinde bir ortaokulda 2016-2017 eğitim-öğretim yılı bahar yarıyılında, beşinci sınıfta öğrenim gören 70 öğrenci üzerinden alınmıştır. Araştırmanın işlem basamaklarında ilk olarak resimli çocuk kitapları öğrencilere sesli bir şekilde okunmuş ve resimler gösterilmiştir. Kitapların bütün öğrenciler tarafından okunması tamamlandıktan sonra öğrencilere okudukları metinler hakkında sözlü anlatımlar yaptııımıştır. Bu aşamaların bitiminde son olarak, öğrencilerden formdaki soruları yazılı olarak cevaplamaları istenmiştir. Elde edilen verilerin çözümlenmesinde kategorisel çözümleme yaklaşımı tercih edilmiştir.Bu çözümlemede Ulusoy'un (2016) "Resimli Çocuk Kitapları ve Okur-Tepki Teorisi” adlı makalesinde kullandığı kategorilerden yararlanılmışıır. Yapılan çözümlemede ortaokul beşinci sınıf öğrencilerinin cevaplarında okur odaklı tepkilerin metin odaklı tepkilere oranla daha önde olduğu sonucuna ulaşılmıştır. Katılımcıların resimli çocuk kitaplarına ilişkin tepkilerinin anlaşılması için elde edilen bulgular konu ile ilgili yapılmış benzer çalışmalarla karşılaştırılmıştır.
\end{abstract}

Anahtar Kelimeler: Ortaokul öğrencileri, resimli çocuk kitapları, okur-tepki kuramı.

A Study on the Responses of Secondary School Students to Illustrated Children's Books

\begin{abstract}
The role of readers in comprehending and interpreting literary texts is important. Readers havean effective role in analysing the text and reproducing the meaning. For this reason, readers should be competent and equipped with knowledge and skills in literary reading process. In this process which is based on reading skills the reader comprehends with receptive skills, sensitivity, and consciousness. In this study, it was aimed to analyse the written feedback of the fifth grade students of secondary school to illustrated children's books in terms of reader response theory. The research was designed by using case study from qualitative research method. The data was collected from 70 students in the fifth grade in the spring semester of the 2016-2017 academic year in a secondary school in Tokat. At the beginning of the research process, children's picture books were read aloud to the students and pictures were shown. After it was completed, all students were asked to give oral feedback on the texts they read. At the end of these stages, students were asked to fill out a questionnaire. Categorical analysis approach was preferred in examining the data. In this analysis, Ulusoy's (2016) article titled as "Picture books and Reading
\end{abstract}

*Dr. Öğr. Üyesi, Tokat Gaziosmanpaşa Üniversitesi, Eğitim Fakültesi, Türkçe ve Sosyal Bilimler Eğitimi Bölümü, Tokat, beytullah.karagoz@gop.edu.tr; Orcid: http://orcid.org/0000-0003-2966-8226. 
Response Theory" was used in the category. As a result of the analysis, it was concluded that the responses of the fifth grade students in the secondary school were more reader-focused than the text-based responses. Findings of participants' perception of their reactions to illustrated children's books were compared with similar studies.

Keywords: Secondary school students, illustrated children's books, reader-response theory.

\section{Giriş}

Okuma "bir yazıda ne yazıldığını sadece gözle veya aynı zamanda seslendirerek çözmek; yazının anlamlı ses haline dönüşmesi" olarak tanımlanır (Ayverdi, 2011: 946; Demirel, 1999: 50). Bununla birlikte okuma, zihinsel ve düşünsel analiz yoluyla anlam yaratmaya dayalı bir dil becerisidir. Başka bir anlatımla "okumadan maksat anlam kurmaktır" (Akyol, 2011: 1). Bu bağlamda okur, okuma sürecinde basılı ve yazılı simgelerle iletişimsel bir etkinlik içine girerken kurgusal dünyada sonu belirsiz bir bulgulama eylemi içerisindedir (Bennett ve Royle, 2004; Kula, 2008; Özdemir, 1997; Rosenblatt, 1982).

Bir metin "okuyucu bunları anlamlı semboller dizisine dönüştürene kadar sadece mürekkep lekesi olarak kalır" ve metindeki anlam inşası bir okuyucu tarafından tamamlanır. Okur, metin ile kendi gerçek dünyası arasında sürekli bağlantı kurar; bunu yaparken edebiyatı okumanın sadece dünya hakkında bilgi vermediğini, ayrıca "yaşamak" için bir deneyim sağladığını da keşfeder" (Rosenblatt, 1983: 24-38). Bu farkındalık okurun okuma eylemi sırasında yazarın yazdıklarını yeniden yaşamasını, ona bir yaratım gücü katmasını sağlar (Binyazar, 2010). Öte yandan okur "kendisine sunulan kurmacasal evreni, kendi imgelem gücüne göre ya büyütür ya da küçültür" (Özdemir, 2002: 24). Böylece "bir yazınsal yapıtı bireysel ya da tekil düzeyde tümler" (Kula, 2012: 13). Bu bağlamda metin keşfedilmeyi bekleyen gizli bir hazinedir. Bu örtülü gerçekliği bulup çıkarmak için okurun deneyim ve birikimine gereksinim duyulur. Okur bilincini, duyarlılığını var olan düşünsel örüntü içinde etkinleştirir. Buna göre okuma uğraşının temelinde okurun zihinsel çabası önceliklidir. Okur bu yönüyle metnin doğasını anlama ve yorumlama uğraşında başat ögedir. Bir iz sürücü olarak kendinden eklemelerle metni gizemden arındırır. Böylece anlamı kişisel bir düzeye indirgemiş olur.

"Her sanatçı, her yazar yapıtıyla hedef kitlesine bir şey anlatma çabasındadır" (Dilidüzgün, 2002: 43).Bu işleviyle okuma, yazarın "metne içkinleştirdiği, insan, toplum ve dünya anlayışının, değer yargılarının, politik tavrının, estetik derinliğinin veya yüzeyselliğinin ayrımına varma uğraşıdır" (Kula, 2016: 156). Bu dizgede okur olası bilgi, beklenti ya da motivasyonları ile metne yaklaşır (Scott, 1994). Bu yönüyle yazar, metin üzerindeki başat konumunu okurla paylaşır. Okurun yapıttaki boşlukları, belirsizlikleri kendi dünya bilgisi, duygu ve düşünce yeterliği, kendine özgü kişiliği, görüş ve düşünceleri ile okuduklarına kendini kaptırmadan kendi kararlarını vererek doldurmasını bekler. Bu süreçte metnin kendisi aynıdır, ama alımlanması uğraşında her yeni okurla sürekli "yeni" bir metne dönüşür, çünkü bu edimin art alanında her okurun kendi deneyim ve birikimi yer alır. Bu nedenle 
Ortaokul 5. Sınıf Öğrencilerinin Resimli Çocuk Kitaplarına İlişkin Tepkileri Üzerine Bir İnceleme

yapıtla okuyucu arasında kurulan ilişki ve etkileşim aracılığıyla "okuyucunun edindiği deneyimler, sürekli olarak okuyucunun sergilediği tutumca doğrulanır, olumlanır, sorgulanır; sağlamlaştırılır ya da düzeltilir" (Sever, 2013;Yüce, 2016; Parla, 2017; Kula, 2012: 130). Böylece yazar-yapıt ve okur dizgesi birbirlerini etkileyen, besleyip zenginleştiren bir etkileşim ortamı ve olanağına dönüşür.

Bu görüşler edebiyat dünyasında çok bilinen okur-tepki kuramına dayanmaktadır. Okur-tepki kuramı 1920'lerde I.A Richards tarafından kavramsallaştırılmıştır. Bu kavram, 1930'lu yıllarda D.W. Harding ve L. Rosenblatt tarafından daha da ileri götürülmüştür. 1970'lerde Konstanz Ekolü'nü temsil eden Wolfgang Iser ve Hans-Robert Jauss ile ABD'li Stanley Fısh'in okurun anlamın oluşturulmasındaki etkin rolüne yaptıkları titiz vurguyla, okur-tepki kuramı yazınsal eleştiri geleneğinde belirginleşmiştir. (Kavalcı, 2017; Zainal vd., 2010).

Kurama göre okur, anlamın belirlenmesi ve metnin yaşanmasında önemli rol oynayan, yönü belirleyen öncelikli bir aracı olarak kabul edilir (Davis ve Womack, 2002; Ekiz, 2007; Özbek, 2013; Padley, 2006; Şimşek, 2013).Bu anlamda kuram, okurun okuduklarına kişisel olarak cevap vererek inşa ettiği işlemsel süreçte bir esere nasıl tepki verdiğini inceleyen bir yaklaşım ve tekniği kapsamaktadır (Rosenblatt, 1978; Schraw ve Bruning, 1996; Sipe, 2008). Kuram, "okuru edilgen durumdan çıkararak, karakter, olay, zaman ya da mekân ile ilgili karanlık bırakılmış birçok noktayı çözmeye davet eder" (Moran, 2003: 240). Okur-tepki kuramının merkezinde, her bir okuyucu, kişisel anlam yaratma ve önceki deneyimler yoluyla yaşamı metne dâhil ettiği için, okurun ve metnin etkileşimi yer almaktadır (Larson, 2009).

Okur odaklı tepki kuramının önemli bir diğer kuramcısı olan Stanley Fish (1970) anlamın, metinden daha öte okurun özünde var olduğunu dile getirir. Araştırmacı anlamı bir deneyim biçiminde açıklar. Tyson (1999) okur odaklı kuramcıların iki görüşe sahip olduğunu savunur: (1) Okurun rolü, edebiyat algısından, anlayışından ayrı tutulamaz. (2) Okurlar, kendilerine yazınsal bir metin ile sunulan anlamı edilgen bir biçimde tüketmezler, tersine yazınsal türde buldukları anlamı etken bir biçimde kendileri yaratırlar. Culler (1981) de metin ve okur arasında bir etkileşim olduğunu bildirir. Holland (1975) ise okur odaklı kurama psikolojik açıdan yaklaşır; okurların yorum ve tepkilerinin metinlerden daha çok okur hakkında bilgi verdiğini, okuru ortaya çıkardığını düşünür. Buna göre okurun metne yaklaşımının niteliğini etkileyen bir dizi etken bulunduğu söylenebilir. Cevaplar, ahlak ve dinsel kodlardan, ailenin ve toplumun geçmişinden gelen felsefe, geçmiş deneyimler ve diğer yazınsal deneyimlerden etkilenmektedir (Rosenblatt, 1978; Smith, 1992; Sumara, 1996). Göktürk (2012: 105-107) anılan durumu şu belirlemelerle açıklar:

“Nesnel yaşam gerçeği ile nesne ötesi gerçek arasında bir sarkaç gibi salınan okur algısıyla, bilinç yeni bakış olanakları kazanır, bulunduğu tarihsel noktadan, kendi 
bireysel konumundan, çağının yaşantı dağarcığından, metnin iletisini alımlar. Bu aşamada metnin anlamı, bizim yaşantılarımıza kattığı boyutla bizden bir parça olur."

Bu bağlamda, okuma eyleminde anlamı oluşturan sadece bir dizi sentez ve seçim değil, aynı zamanda anlama eklenen düşünce ve duygu boyutudur (Ötgün, 2008). Çünkü okur duygularını, algılarını metinle uyum sağladığını düşündüğü yeni deneyimlere bağlar. Hikâyeye katılır, kendisini karakterlerle özdeşleştirmek suretiyle onların çatışmalarını ve duygularını paylaşır (Rosenblatt, 1982). Bu yanıyla "okur merkezli böyle bir okuma, sınıf içinde de yararlı olacak, bilinçli bir okuyucuya estetik bir haz da verecektir. Okuyucu/öğrenci kendince yeni ufuklara açılabilecek, yazınsal metni kendi gününe, kendi yaşamına çekebilecektir" (Uçan, 2006).

Ana dili ve edebiyat eğitiminde okur-tepki kuramından yararlanıldığı bilinmektedir. Bir anlama yaklaşımı olarak okur-tepki kuramı, öyküleyici ve bilgilendirici metinleri çözümleme araştırmalarında kullanılmaktadır. Bu çerçevede alanyazında dördüncü sınıf öğrencilerinin (Swaggerty, 2006), ortaokul öğrencilerinin (Galda ve Beach, 2001), lise öğrencilerinin (Smith, 1991) tepkileri üzerine yoğunlaşan araştırmalar olduğu görülmektedir.

Swaggerty (2006) dördüncü sınıfa devam eden başarılı okuyuculardan oluşan küçük bir grubun beş postmodern resimli kitap üzerinde kullandığı anlama stratejilerini incelemiş ve okuma başarısına etki eden faktörleri belirlemeye çalışmıştır.

Galda ve Beach (2001), araştırmalarında ortaokulda öğrenim gören gönüllü öğrencilerin gençlik edebiyatı metinlerine ilişkin tepkilerini belirlemeyi amaçlayan bir araştırma gerçekleştirmişlerdir. Araştırmacılar öğrencilerin cevaplarına dayalı çalışmaların okuma ve cevap verme fırsatları yaratarak öğrencilerin metinsel içeriği ve yaşadıkları dünyayı anlama yeteneklerini geliştirebileceğini ifade eder.

Smith (1991), dokuzuncu sınıfta öğrenim gören beşi başarılı, diğer beşi daha az başarıı okuyucunun anlatı metninden anlam inşa etme süreçlerine odaklanmıştır. Deneysel nitelikli bu çalışmada başarılı okuyucuların, anlama ve yorumlama uğraşında kişisel deneyimlerine daha fazla güvenme eğiliminde oldukları sonucuna varılmıştır.

Alanyazındaki diğer çalışmalara bakıldığında Türkyılmaz, Can ve Karadeniz (2010) araştırmalarında okur merkezli yaklaşımın ve alımlama estetiğinin Eski Türk Edebiyatı eğitimine uygulanabilirliğini ve yapılan uygulamaların öğrencilerin beklentilerini nasıl karşıladığını belirlemeye çalışmıştır. Araştırmacılar, çalışmalarda alımlama estetiğinden yararlanılması gerektiğini öne sürmektedirler.

Bülbül (2012), makalesinde Alman Dili Eğitimi bölümünde öğrenim görmekte olan 1. ve 4. sınıf öğrencilerinin katılımıyla Heinrich T. Böll'ün bir öyküsünü katılımcıların görüşleri ekseninde 
Ortaokul 5. Sınıf Öğrencilerinin Resimli Çocuk Kitaplarına İlişkin Tepkileri Üzerine Bir İnceleme

irdelemiştir. İnceleme sonucunda farklı gruplardan oluşan öğrencilerin metne dönük yeni bakış açıları kazandığını belirlemiştir.

Ulusoy (2016) makalesinde ilkokul 2. sınıfta öğrenim gören öğrencilerin öyküleyici çocuk kitaplarına yönelik beklenti düzeylerini değerlendirmiştir.

Yekeler ve Ulusoy (2017) araştırmalarında ilkokul 4.sınıfta öğrenim gören öğrencilerin bilgilendirici resimli çocuk kitaplarına ilişkin tepkilerini belirlemeyi amaçlamıştır. Türkiye'deki alanyazın göz önüne alındığında, okur-tepki kuramının birçok araştırmaya konu edinildiği görülmektedir. Ancak alanyazın ortaokul öğrencilerinin resimli çocuk kitaplarına yönelik tepkilerini inceleyen çalışmalar bakımından boşluk taşımaktadır.Bu çalışma ortaokul beşinci sınıf öğrencilerinin çocuk kitaplarına ilişkin tepkilerini ortaya koyacak nitelikte olduğu için diğer çalışmalardan farklılık göstermektedir.

Resimli çocuk kitaplarının çocuğun varlık bilincini tanımlaması, toplumsallaşması için yardımcı bir gereç olduğu ve yaratıcı düşüncenin gelişmesini sağladığı bilinmektedir (Gönen, 1984). Bu durum öğrenme ve öğretme ortamlarında bu yapıtlara önemli sorumluluklar yüklemektedir. Zira çocuk yayınlarının iletişimsel doğası düşünsel üretime yönlendirici bir içerik taşır. Buna göre çocuğun resimli çocuk kitapları ile girdiği etkileşim belirleyici önemdedir. Bu olgudan hareketle çocukların resimli çocuk kitaplarına ilişkin yazılı tepkilerinin belirlenmesi gereklidir ve bu konu giderek önem kazanmaktadır. Alanyazında ilkokul 1. Sınıf öğrenicileriyle yürütülen bu tür çalışmaların heyecan verici keşiflere yol açtığı belirtilmektedir (Wollman-Bonilla ve Werchadlo, 1995). Gelişim psikolojisi açısından farklı bir gelişim döneminde olan ortaokul 5. sınıf öğrencilerinin cevaplarının ilkokul kademesindeki öğrencilerden farklılık gösterebileceği düşüncesi ile araştırmanın sonuçları önemli görülmektedir. Mevcut araştırmada, ortaokul 5.sınıf öğrencilerinin Kırmızı Kanatı Baykuş ve Gazoz Çeşmesi isimli iki resimli çocuk kitabına yönelik tepkilerini ortaya çıkarmak amaçlanmıştır. Çalışma bu temel amaçla birlikte, aynı zamanda Türkçe Dersi Öğretim Programı (MEB, 2017) 5.sınıf Türkçe dersi kazanımlarında yer alan "Dinleme/izzleme, Konuşma, Anlama" beceri alanlarındaki kazanımlarla da illişkilidir.Bu çerçevede çalışmanın "dinlediklerinin/izlediklerinin içeriğini değerlendirme, hazırlıksız konuşma yapma, metni yorumlama, metinle ilgili sorulara cevap verme" kazanımlarına ulaşma noktasında öğrencilerin gelişimine katkıda bulunacağı düşünülmektedir. Bu doğrultuda Ulusoy'dan (2016) uyarlanarak hazırlanan araştırma soruları şunlardır:

1. Ortaokul beşinci sınıf öğrencilerinin metin ve okur odaklı yazılı tepkileri nelerdir?

2. Ortaokul beşinci sınıf öğrencilerinin metin ve okur odaklı tepkileri nasıl bir dağıım göstermektedir? 


\section{Yöntem}

\section{Araştırmanın Modeli}

Çalışma ortaokul 5.sınıf öğrencilerinin Feridun Oral tarafından yazılıp resimlenen ve 2012 yılında yılın en iyi resimli öykü kitabı ödülüne değer görülen Kırmızı Kanatı Baykuş ile Mevlana İdris Zengin'in kaleme aldığı resimlemesini Dağıstan Çetinkaya'nın gerçekleştirdiği Gazoz Çeşmesi adlı iki resimli çocuk kitabına ilişkin yazılı görüşlerini belirlemeye odaklanmıştır. Bu nedenle araştırmada durum çalışması yaklaşımı benimsenmiştir. Durum çalışması sınırlı bir sistemin derinlemesine betimlenmesi ve incelenmesi, güncel bir olgunun gerçek bağlamında incelenmesidir (Merriam, 2013; Yin, 2003). Eğitimsel durum çalışmalarında tipik gruplar, bir sınıftaki öğrenciler, aynı sınıf düzeyinde eğitim veren öğretmenler ya da engelliler sınıfında öğrenme güçlüğü çeken öğrenciler olabilmektedir (McMillan, 2004).

\section{Çalışma Grubu}

Çalışma grubu Tokat il merkezinde bir devlet ortaokulunda 5. sınıfta öğrenim gören toplam 70 öğrenciden oluşmaktadır. Öğrencilerin \%48.57'si kız ( $n=34)$ ve \%51,42'si erkektir $(n=36)$. Çalışmada amaçlı örnekleme yöntemlerinden kolay ulaşılabilir durum örneklemesi kullanılmıştır. Kolay ulaşılabilir durum örneklemesi araştırmaya hız ve pratiklik kazandırır. Çünkü bu yöntemde araştırmacı yakın olan ve erişilmesi kolay olan bir durumu seçer (Yıldırım ve Şimşek, 2011). Çalışmaya katılacak öğrencilerin seçiminde gönüllülük ve isteklilik ön planda tutulmuştur.

\section{Verilerin Toplanması}

Çalışmanın verileri Ulusoy'un (2016) Hancock'tan (2008) uyarlayıp geliştirdiği dört soruluk bir form ile toplanmıştır. Çalışmada öğrencilerin resimli çocuk kitaplarına ilişkin yazılı görüşlerini belirlemek için iki farklı çocuk kitabı kullanılmıştır. Bu kitapların seçiminde çocuk bakışını yansıtma, çocuk gerçekliğine uygunluk ve yazarlarının alandaki bilinirliği ilkeleri gözetilmiştir. Çalışmada kullanılan ilk eser, Kırmızı Kanatı Baykuş adlı resimli çocuk kitabıdır. Kitabın öyküsü ve resimlemesi Feridun Oral'a aittir. Kitap, 2012 yılında "Yılın En İyi Resimli Öykü Kitabı" ödülünü kazanmıştır. Metinde uçamamaktan ve kanatlarının bir türlü kızarmamasından yakınan yavru bir baykuşun, arkadaşı farenin yardımı ve yüreklendirmesiyle yaşama bağlanması, amaca ulaşma yolundaki tutumu betimlenmektedir. Metinsel içerikte, çocuk okura dış motivasyonun kişiyi belli bir yere kadar götürebileceği, ancak iç motivasyonun başarıya ulaştıran temel etken olduğu iletisi belirgindir.

Çalışmada kullanılan ikinci kitap Mevlana İdris Zengin'in kaleme aldığı resimlemesini Dağıstan Çetinkaya'nın üstlendiği Gazoz Çeşmesi'dir. Kitap Mevlana İdris Zengin'in kurmaca bir dünyada farklı hayvan karakterlerin düşündürücü ve ilginç serüvenlerini konu alan Acayip Hayvanlar serisinin onuncu eseridir. Kitapta yavru bir filin, annesinin sözünü dinlemeyip bir okulun önünde öğrencilerle 
karşılaşması ve çocukları çok seven bu filin onlara gazoz ve sütlü kahve ikram etmesi anlatılır. Sevgi, paylaşma, dayanışma gibi insanlık değerlerinin toplumsallaşma açısından varlığı ve öneminin gereği vurgulanır.

Çalışma için daha önce Ulusoy'un (2016) benimsediği çalışma stratejisinden yararlanılmıştır. Verilerin toplanması 2016-2017 eğitim-öğretim yılı bahar döneminde her iki kitap için iki farklı oturumda gerçekleştirilmiştir. Her uygulama için öğrencilere 60 dakika süre tanınmıştır. Öğrencilerin seçilen kitaplara yönelik görüşlerini elde edebilmek için şu süreçler izlenmiştir: illk aşamada resimli çocuk kitapları öğrencilere sesli bir şekilde okunmuş ve resimler gösterilmiştir. Öğrencilerin dinlediklerini algılayıp algılamadıklarını anlamak için sözlü olarak sorular sorulmuş ve gerek duyulan durumlarda kitaplar yeniden okunmuştur. Kitapları daha iyi anlamak adına inceleme isteğinde bulunan öğrencilere kitapları inceleme olanağı verilmiştir. Kitapların bütün öğrenciler tarafından okunması tamamlandıktan sonra öğrencilere okudukları metinler hakkında sözlü anlatımlar yaptırılmışır. Böylelikle kitaplardaki konu ve karakterleri anlayıp anlamadıkları belirlenmeye çalışılmıştır. Bu işlem sırasında araştırmacı yansız bir yaklaşımla katıımcıların cevaplarını içerik açısından yönlendirmemeye özen göstermiş, kitaplardaki anlatımlar üzerine olumlu veya olumsuz herhangi bir tepkide bulunmamıştır. Bu işlemlerin bitiminde her kitap için öğrencilerden Ulusoy'un (2016) Hancock'tan (2008) aktardığı aşağıdaki soruları yazılı olarak cevaplamaları istenmiştir.

1. Bu kitap kendini nasıl hissetmeni sağladı? (estetik)

2. Bu kitabın kendi hayatınla veya tanıdığın biri ile ilgili hatırlattığı şeyler var mı? (deneyimsel)

3. Bu kitapta senin için hangi mesajlar veya anlamlar var? (yorumlayıcı)

4. Eğer kitaptaki karakterlerden biri olmak isteseydin hangisini seçerdin ve neler yapmak isterdin? (bilişsel)

Araştırmacı çalışmanın ön hazırlık aşamasında alan uzmanı olarak çalışma konusu ile ilgili kuramsal okumalar yapmıştır. Veri toplama sürecini yöneterek elde edilen verileri analiz etmiş ve ulaşılan sonuçları rapora dönüştürmüştür.

\section{Verilerin Analizi}

Bu çalışmada ortaokul 5.sınıf öğrencilerinin resimli çocuk kitaplarına ilişkin yazılı görüşleri metin merkezli cevaplar-okur merkezli cevaplar açısından içerik çözümlemesi yöntemi ile değerlendirilmiştir. Çalışmada içerik çözümlemesi türlerinden biri olan kategorisel çözümleme kullanılmıştır. Çalışmanın verileri çözümlenirken, Wollman-Bonilla ve Werchadlo (1995) tarafından geliştirilen Ulusoy'un (2016) çalışmasında uygulayarak düzenlediği kategoriler temel alınmıştır. Çalışmada yararlanılan kategoriler şu şekildedir: 
Metin merkezli cevaplar: Hikâyeyi yeniden anlatma, Karakterleri anlama, Soru sorma, Tahmin etme, Ana fikir

Okur merkezli cevaplar: Kişisel tepki (düşünceler ve hisler), Hikâye ile deneyimleri arasında bağlantı kurma, Hikâyedeki olaylara katılma isteği

Verileri çözümleme aşamasında katılımcıların vermiş olduğu cevaplar incelenerek uygun kategorilerin altında kodlanmıştır. Daha sonra bu kodlar toplanarak sıklık değerleri çıkarılmış ve tablo olarak sunulmuştur. Elde edilen verilerden önemli olduğu düşünülen örnekler tabloların altında doğrudan alıntılarla verilmiştir. Öğrenci cevaplarından alıntılanan örnekler öğrenci kod numaraları ile belirtilmiştir.

\section{Bulgular}

Bu bölümde çalışma grubundaki öğrencilerin resimli çocuk kitaplarına ilişkin tepkilerini belirlemek amacıyla hazırlanan soruların uygulanmasından elde edilen bulgulara yer verilmiştir. Aşağıda öğrencilerin Kırmızı Kanatı Baykuş kitabı ile ilgili yazılı görüşlerine ilişkin tablo yer almaktadır.

Tablo 1. Öğrencilerin Kırmızı Kanatıı Baykuş Kitabı Ile Ilgili Yazılı Görüşleri

\begin{tabular}{lc}
\hline Cevaplar & Sıklık \\
\hline Metin merkezli cevaplar & \\
Hikâyeyi yeniden anlatma & 3 \\
Karakterleri anlama & 47 \\
Soru Sorma & - \\
Tahmin Etme & 3 \\
Ana fikir & 32 \\
\hline Okur merkezli cevaplar & \\
Kişisel tepkiler (düşünceler ve hisler) & 62 \\
Hikâye ile deneyimleri arasında bağlantı kurma & 37 \\
Hikâyedeki olaylara katılma isteği & 54 \\
\hline
\end{tabular}

Tablo 1 öğrencilerin Kırmızı Kanatı Baykuş kitabına verdikleri cevapların dağılımını göstermektedir. Tablodan görülebileceği gibi, katılımcıların daha çok okur odaklı cevaplar verdiği, metin odaklı cevapların daha az olduğu belirlenmiştir. Öğrencilerin en çok vurguladığı cevabın kişisel tepkilere yönelik cevaplar olduğu görülmüştür. İkinci sırada ise hikâyedeki olaylara katılma isteği yer almaktadır. Bu örüntü öğrencilerin metnin kurgusunu çözümleyerek kendi anlam dünyaları ile metnin anlam evreni arasında bağlantı kurmak suretiyle metne dâhil olmak istediklerine bir kanıt oluşturabilir. Tablo 1'de öğrencilerin metne ilişskin soru sormadığı az bir kısmının ise tahmin etme ve hikâyeyi yeniden anlatma kategorisine cevap verdiği görülmektedir.

Hikâyeyi Yeniden Anlatmaya iliş̧kin Bulgular

Bulgulara göre üç öğrencinin sorulara verdikleri cevaplarda hikâyeyi yeniden anlatmaya çalıştığı gözlemlenmiştir. Alıntıdan da anlaşılacağı üzere katılımcılar, hikâyeyle ilgili yeni anlamlar, 
Ortaokul 5. Sınıf Öğrencilerinin Resimli Çocuk Kitaplarına İlişkin Tepkileri Üzerine Bir İnceleme

çıkarımlar yapmaktan daha çok hikâyeyi tekrardan anlatma çabası içerisine girmişlerdir. Bu durum, öğrencilerin metnin iletisini kavramakta, anlama ortak olma sürecinde sorunlar yaşadığına işaret etmektedir. Örneğin Ö 65 tarafından verilen cevap aşağıda yer almaktadır.

Örnek 1. 65 numaralı katıımcının verdiği cevap

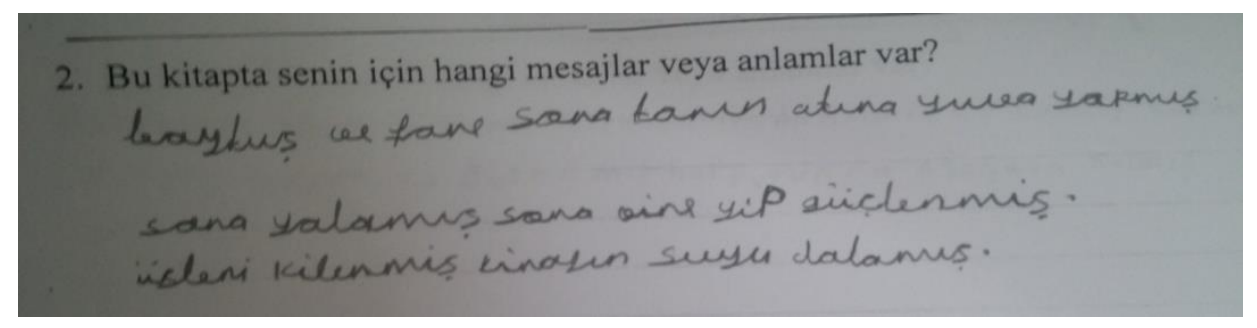

Karakterleri Anlamaya ilişskin Bulgular

Hikâyenin ana karakterleri fare ile baykuştur. Hikâyede 43 öğrenci baykuş, 20 öğrenci fare, 2 öğrenci ise kediyi ana karakter olarak seçmiştir. 5 öğrencinin ise karakterleri anlama konusundaki cevaplarının yetersiz olduğu anlaşımaktadır. Örnek görseller (2-3), öğrencilerin hikâyede yer alan karakterleri iyi anladığını göstermektedir; ancak karakterleri seçme konusunda öğrenciler arasında farklılıklar bulunmaktadır.

Örnek 2. 25 numaralı katılımcının verdiği cevap

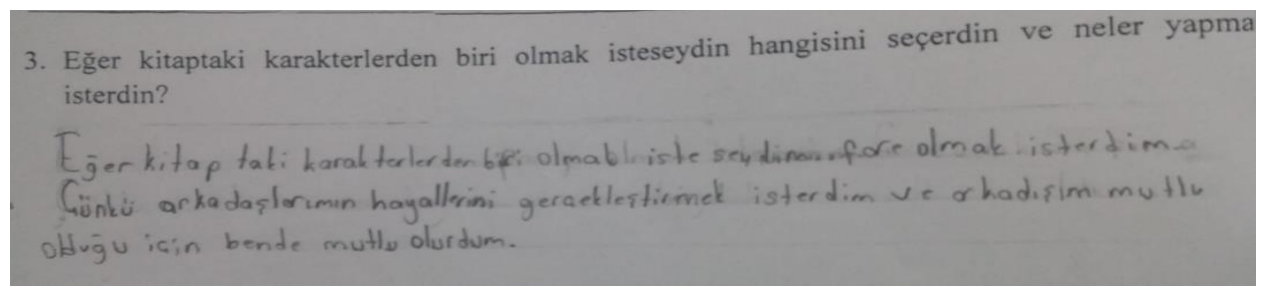

Örnek 3.48 numaralı katıımanın verdiği cevap

3. Eğer kitaptaki karakterlerden biri olmak isteseydin hangisini seçerdin ve neler yapma isterdin?

Eger kitap

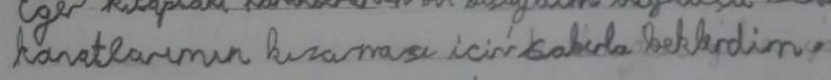

Tahmin Etmeye ilişkin Bulgular

Öğrencilerin sadece kişisel tepkilere değil, aynı zamanda tahminlere de yer verdikleri görülmektedir. 4 numaralı görsele gore öğrencinin kişisel tepkisine bakıldığında, hikâyenin içinde olduğu, hikâyeyi bizzat yaşadığı, zavallı baykuş diyerek baykuşun uçamamasına içerlediği ve baykuşun sonunda uçabilmesine kendisi uçmuş gibi sevindiği görülmektedir. "Fare ile baykuş arkadaş olmasaydı, kim bilir zavallı baykuş ne yapardı" diyerek bu duruma yönelik tahminde bulunduğu gözlenmektedir. 


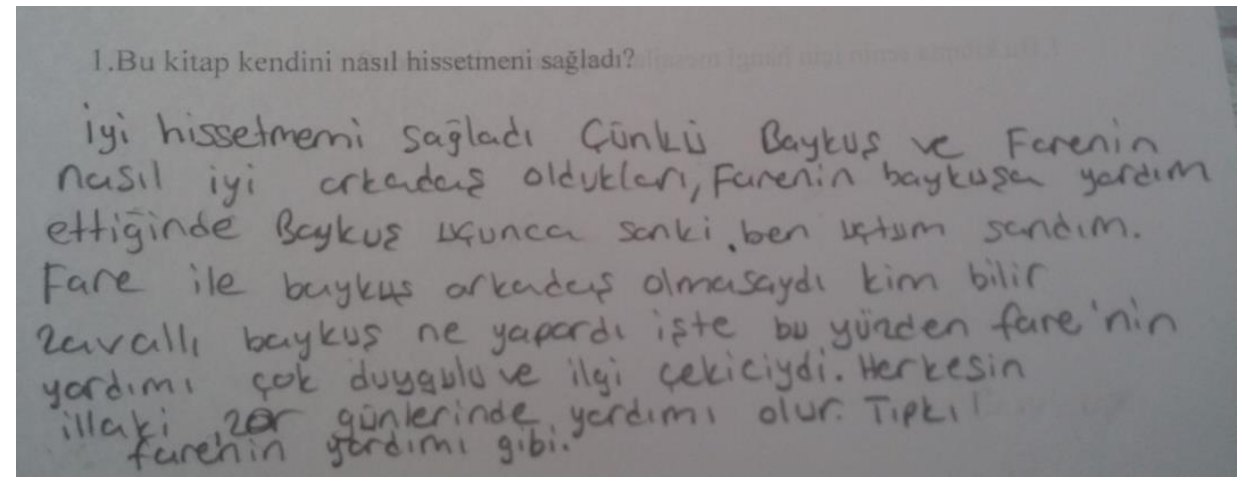

Ana fikire ilişskin Bulgular

Katılımcılar okudukları hikâyelerin ana fikirlerini doğru şekilde belirlemişlerdir. Bu sonuç ilgili kitabın ana fikrini kavradıklarını, ana fikrin bilincine vardıklarını ortaya koymaktadır. Örneğin Ö70 tarafından verilen cevaplardan da anlaşılacağı gibi, katılımcılar yaygın olarak dostluk, arkadaşlık, yardımlaşma, fedakârlık, sabır, iyilik gibi sözcüklerin ağırlıkta olduğu ana fikir cümlelerine yer vermişlerdir.

Örnek 5. 70 numaralı katıımcının verdiği cevap

2. Bu kitapta senin için hangi mesajlar veya anlamlar var?

Dostluk ue Arkadastik aimlami...nar.

\section{Kişisel Tepkiye ilişkin Bulgular}

Katılımcı cevapları incelendiğinde, katılımcıların önce hüzün yaşadıklarını ardından ise mutlu olduklarını dile getirdikleri görülmüştür. Öğrencilerin hüznü yaşama nedenleri, farenin yardımına karşın baykuşun ilk denemelerinde uçamaması ve uçamayacağını düşünmeleri iken; mutluluğu ve sevinci yaşama gerekçeleri ise baykuşun uçabilme yeteneğini elde etmesi olmuştur. Örneğin Ö47 ve Ö62 tarafından verilen cevaplar aşağıda yer almaktadır.

Örnek 6. 47 numaralı katıımcının verdiği cevap

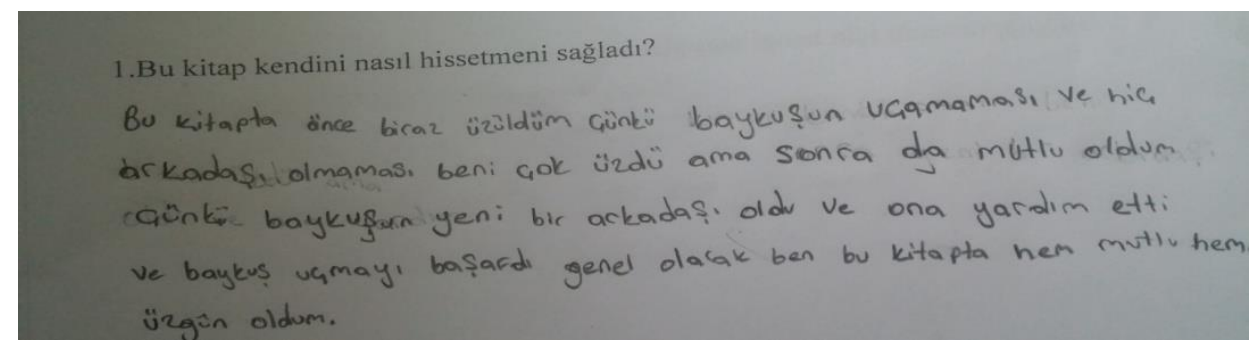


Örnek 7. 62 numaralı katılımcının verdiği cevap

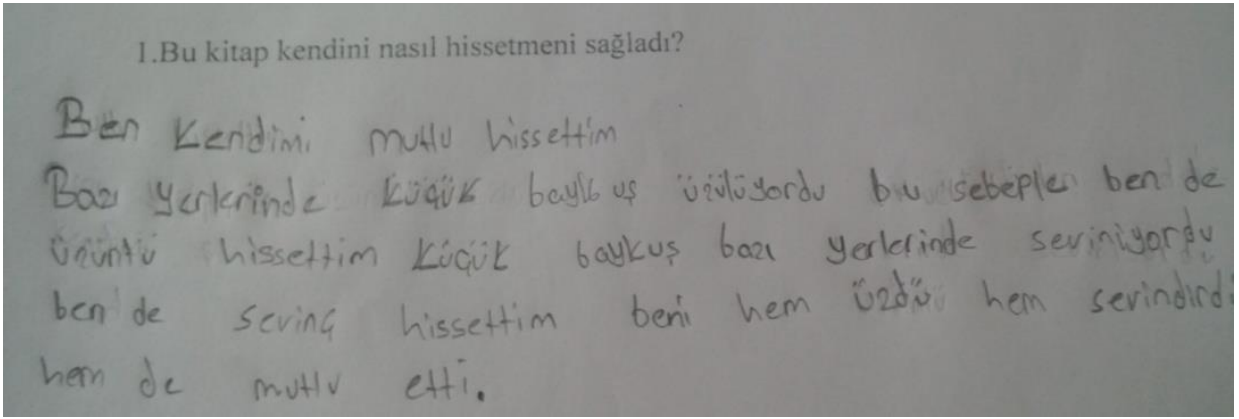

Hikâye ile Deneyimleri Arasında Bağlantı Kurmaya Ilişkin Bulgular

8 ve 9 numaralı görsellere bakıldığında, öğrencilerin temel olarak iyilik, yardımseverlik ve dostluk içerikli deneyimlerini yazdıkları görülmüştür. Katılımcıların deneyimlerini yansıttıkları cümlelerde, hikâyedeki baykuşun uçmak için gösterdiği çabaya, söz konusu çabanın sonrasında gelen başarı üzerinde yoğunlaştıkları anlaşılmaktadır. Öğrenciler aynı zamanda farenin baykuşa yardım etmesine, baykuşun uçması için elinden geleni yapmasına benzeyen kişisel yaşam deneyimlerini de paylaşmaktadır. Örneğin Ö23 ve Ö60 tarafından verilen cevaplar aşağıda yer almaktadır.

Örnek 8. 23 numaralı katılımcının verdiği cevap

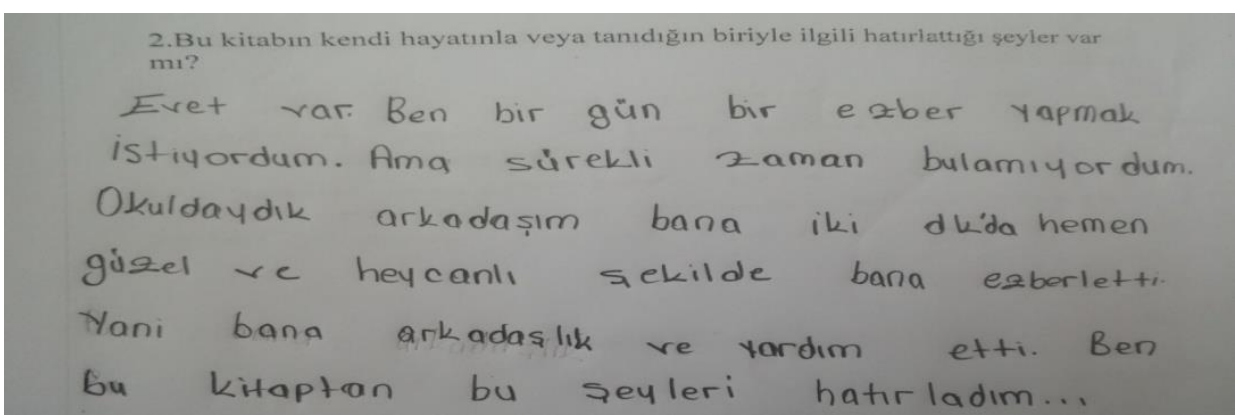

Örnek 9. 60 numaralı katılımcının verdiği cevap

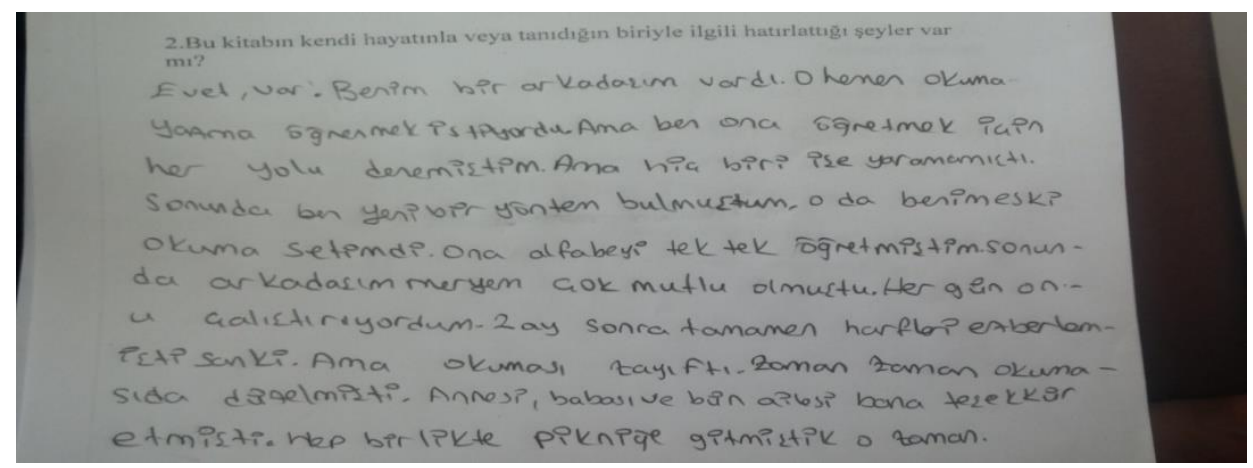

Hikâyedeki Olaylara Katılma İsteğine Ilişkin Bulgular

$\mathrm{Bu}$ kategoriye göre katılımcılar yüksek oranda ( $\mathrm{f=43)}$ "Baykuş olmak isterdim; çünkü uçabilmeyi, farklı yerler görmeyi çok isterim" cevabının yanı sıra "Baykuş olmak isterdim; çünkü uçmak için daha çok çabalardım, daha fazla deneme yapardım” biçiminde tepkiler vermiştir. Bazı 
öğrencilerin hikâyenin kendilerine yansıttığı duyguları somutlamak için cevaplarını kalp görselleriyle süslediği görülmüştür. Öğrencilerden fare olmak isteyenlerin $(f=20)$ cevaplarında ise, öğrencilerin "Fare olmak isterim, çünkü ben de yardımlaşmayı, yardım etmeyi, iyilik yapmayı düşünürdüm; yardım için çözüm yolları bulurdum; arkadaşlarımın hayallerini gerçekleştirmeye çalışırdım" gibi anlatımlarda bulunduğu gözlenmiştir. Öğrencilerin cevaplarına bakıldığında, baykuş cevabını verenlerin gerekçelerinde bazı farklılıklar söz konusu iken, fare diyenlerin cevaplarında benzer temaların olduğu görülmektedir. Aşağıda bazı katılımcılar tarafından verilen cevaplar yer almaktadır (Ö12, Ö32, Ö23).

Örnek 10. 12 numaralı katııımının verdiği cevap(Baykuş olmak isterim diyen katılımcılar)

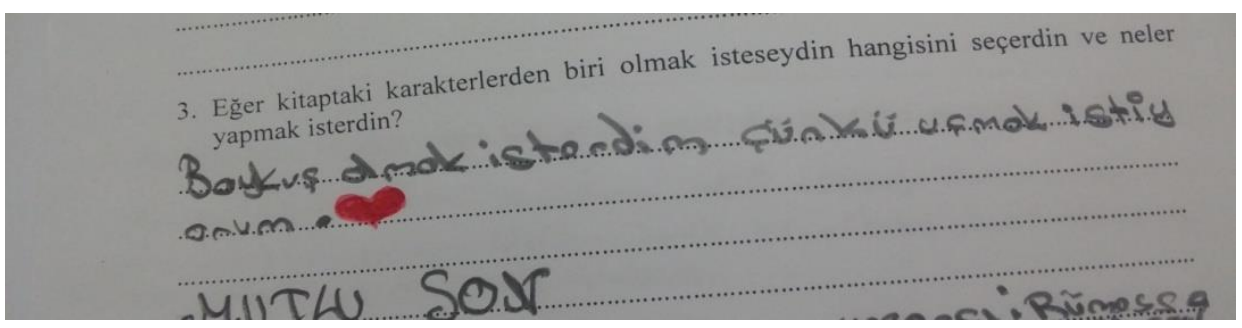

Örnek 11. 32 numaralı katılımcının verdiği cevap

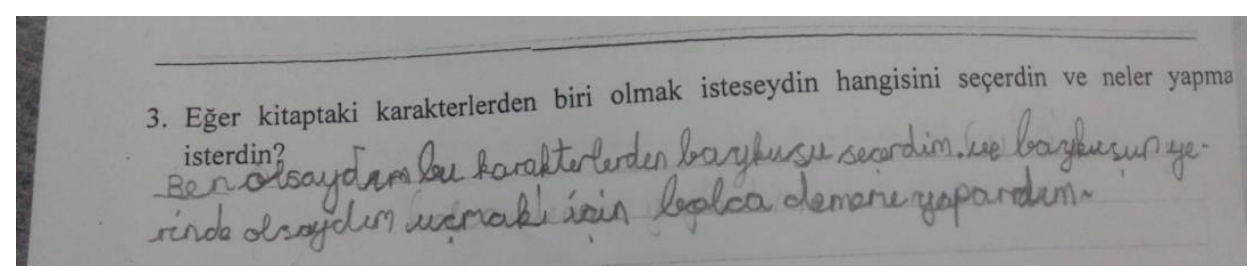

Örnek 12. 23 numaralı katılımcının verdiği cevap(Fare olmak isterim diyen katılımcılar)

3. Eğer kitaptaki karakterlerden biri olmak isteseydin hangisini seçerdin ve neler yapn isterdin?

Kitapdaki Karakterler den biri olmak isteseydim. Fave-

yí seçerdimve fareninyartiāi y an ar kadas larima yardim

ederdim.

Gazoz Çeşmesi Kitabı İle İlgili Bulgular almaktadır.

Aşağıda öğrencilerin Gazoz Çeşmesi kitabı ile ilgili yazılı görüşlerine ilişkin tablo yer

Tablo 2. Öğrencilerin Gazoz Çeşmesi Kitabı Ile Ilgili Yazılı Görüşleri

\begin{tabular}{lc}
\hline Cevaplar & Sıklık \\
\hline Metin merkezli cevaplar & \\
Hikâyeyi yeniden anlatma & 8 \\
Karakterleri anlama & 49 \\
Soru Sorma & 2 \\
Tahmin Etme & 3 \\
Ana fikir & 33 \\
\hline Okur merkezli cevaplar & \\
Kişisel tepkiler (düşünceler ve hisler) & 64 \\
Hikâye ile deneyimleri arasında bağlantı kurma & 26 \\
Hikâyedeki olaylara katılma isteği & 62 \\
\hline
\end{tabular}


Tablo 2 öğrencilerin Gazoz Çeşmesi kitabına verdikleri cevapların dağılımını göstermektedir. Tablo 2'ye göre, katılımcıların çoğunlukla okur odaklı cevaplar verdiği belirlenmiştir. Buna karşılık metin odaklı cevapların daha az olduğu görülmüştür. Katılımcıların cevapları arasında ilk sırayı kişisel tepkiler (düşünceler ve hisler) almıştır. İkinci sırada ise hikâyedeki olaylara katılma isteğinin geldiği belirlenmiştir. Katılımcıların cevaplarında en az oranda soru sorma ve tahmin etme kategorilerinin olduğu görülmüştür.

Hikâyeyi Yeniden Anlatmaya ilişkin Bulgular

Gazoz Çeşmesi kitabında hikâyeyi yeniden anlatmaya ilişkin olarak verilen cevaplara göre, katılımcıların az bir kısmı ( $f=8$ ) hikâyeyi yeniden anlatma yoluna gitmişlerdir. Bu durum metnin iletisini algılamadaki belirsizliğe işaret etmekle birlikte, burada öne çıkan bulgu öğrencilerin metinle ilgili yorumlar yerine metni kendi anladıkları biçimde özetledikleridir. Örneğin Ö41 tarafından verilen cevap aşağıda yer almaktadır.

Örnek 13. 41 numaralı katıımcının verdiği cevap

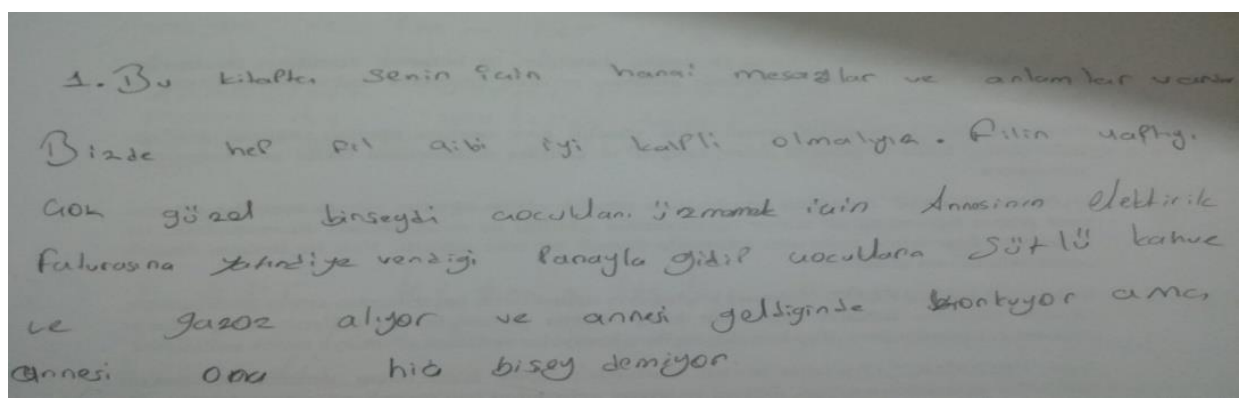

Karakterleri Anlamaya ilişsin Bulgular

Katılımcıların Gazoz Çeşmesi kitabı ile ilgili metin odaklı cevapları arasında"Karakterleri anlama" boyutu ilk sırayı almıştır. Aşağıda sunulan görseller öğrencilerin hikâyedeki karakterleri anladıklarını göstermektedir; ancak karakterlerin seçimiyle ile ilgili farklılıklar olduğu gözlemlenmiştir. Hikâyenin ana karakterleri yavru fil ile çocuklardır. 28 katılımcı hikâyede çocuklardan biri olmak istediğini belirtirken, 34 öğrencinin fil karakterini seçtiği belirlenmiştir. Çocuklardan biri olmak isteyen katılımcılarda çoğunlukla, sütlü kahve ve gazoz içmek, fil ile oynamak istediklerini belirten anlatımlar görülmektedir. Yavru fil olmak isteyen öğrencilerin cevaplarında ise çocuklara gazoz ve sütlü kahve ikram etme, çocukları sevindirme, neşelendirme isteğine ilişkin ifadeler bulunmaktadır.

Örnek 14. 31 numaralı katılımcının verdiği cevap (Çocuk karakterini seçen katılımcı)

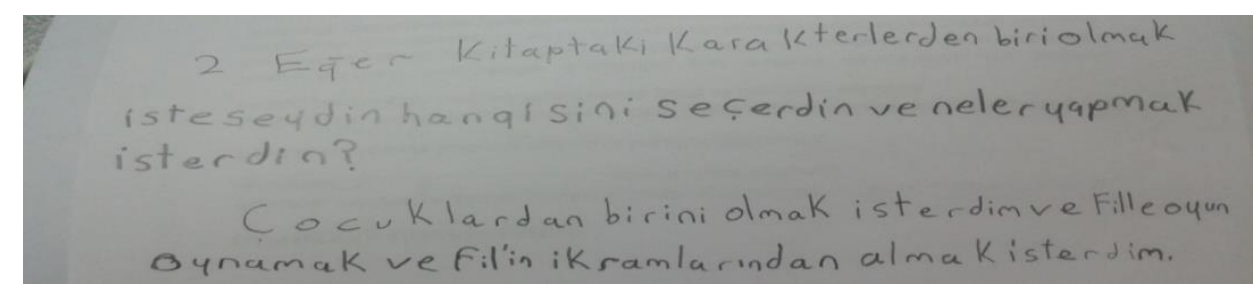






\section{Ana fikire Ilişskin Bulgular}

Katılımcılar Gazoz Çeşmesi kitabının ana fikriyle ilgili çoğunlukla doğru cevaplar vermiştir. Bu durum, katılımcıların metni anlama, yorumlama konusunda yetkin bir konumda olduğunu göstermektedir. Bu kategoride paylaşmanın önemini, ön yargılı olmamanın gerekliliğini vurgulayan anlatımlar söz konusudur. Örneğin Ö4 ve Ö46 tarafından verilen cevaplar aşağıda yer almaktadır.

Örnek 16. 4 numaralı katılımcının verdiği cevap

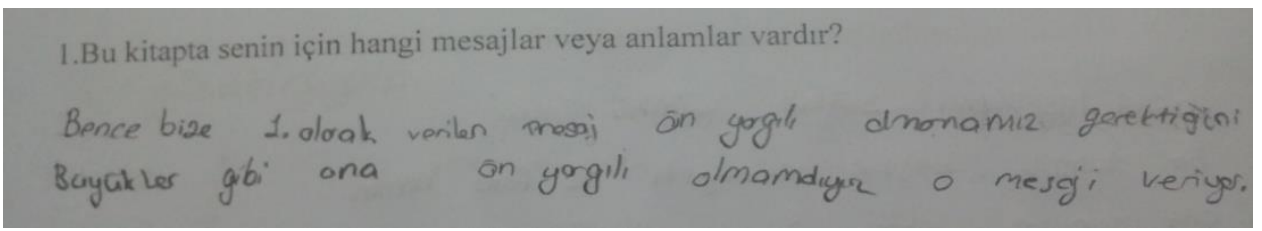

Örnek 17. 46 numaralı katıımcının verdiği cevap

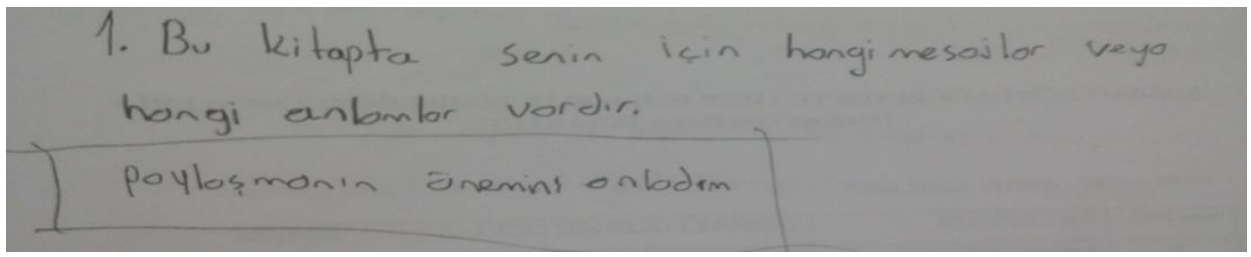

\section{Soru Sormaya ilişkin Bulgular}

Öğrenciler, hikâyenin sonunda annesiyle birlikte çocukların yanından ayrılan yavru file annesinin kızıp kızmadığına ve sütlü kahve ile gazozu yavru filin nasıl çıkardığına ilişkin sorular sormuştur. Öğrencilerin cevapları incelendiğinde, iki öğrencinin hikâyeye dair merak ettiklerini sorma eğiliminde olduğu görülmüştür. Aşağıda Ö62 ve Ö63 tarafından verilen cevaplar yer almaktadır.

Örnek 18. 62 numaralı katıımcının verdiği cevap

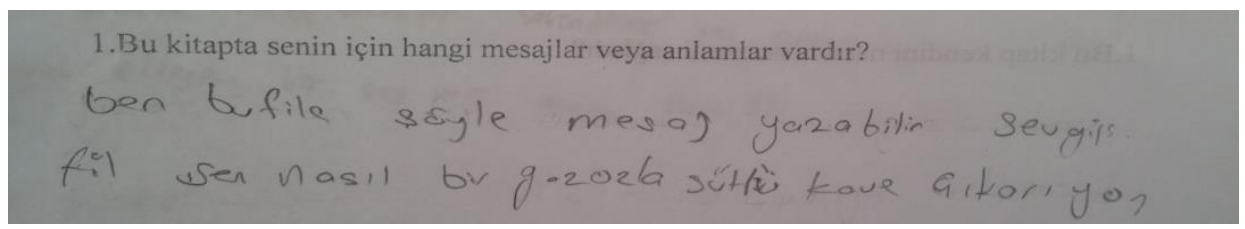


Örnek 19. 63 numaralı katılımcının verdiği cevap



Kişisel Tepkiye ilişkin Bulgular

Öğrencilerin cevapları ele alındığında, çoğunluğun kitabı okumaktan memnun kaldıkları belirlenmiştir. Kendilerini mutlu hisseden bazı öğrenciler, cevaplarına görsel betimlemeler de eklemişlerdir. Şaşkınlık, merak ve üzüntü yaşadıklarını belirten öğrenciler de bulunmaktadır. Örneğin Ö21 ve Ö44 tarafından verilen cevaplar aşağıda yer almaktadır.

Örnek 20. 21 numaralı katılımcının verdiği cevap

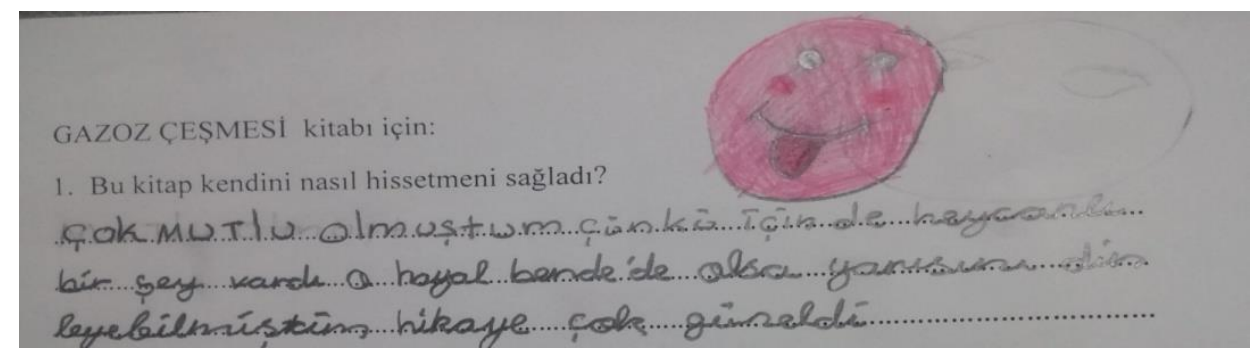

Örnek 21. 44 numaralı katılımcının verdiği cevap

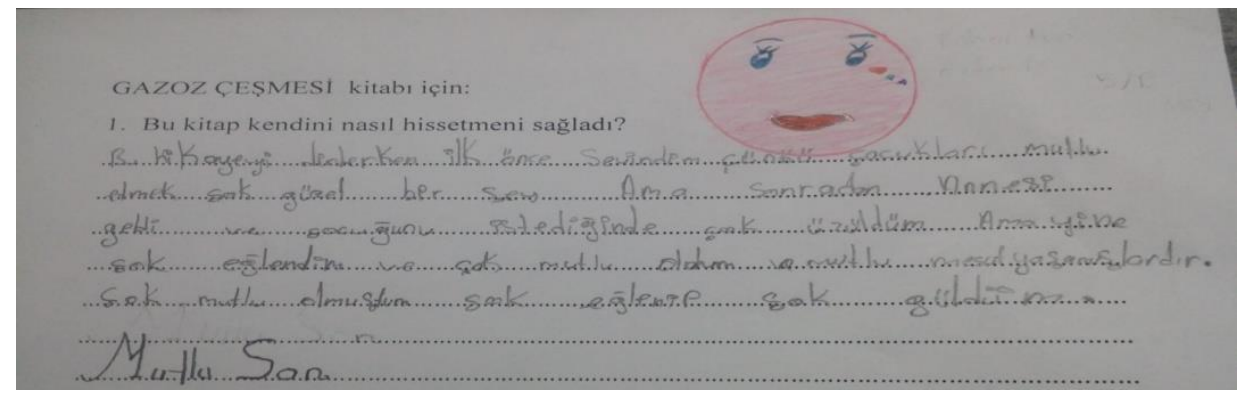

Hikâye ile Deneyimleri Arasında Bağlantı Kurmaya Ilişkin Bulgular

Bulgular incelendiğinde öğrencilerin hikâyeden kendi deneyimlerine, geçmiş yaşantılarına yakın bölümleri seçtikleri gözlenmiştir. Öğrencilerin cevaplarında iyilik yapmak ile ilgili yaşadıkları kişisel bir deneyimi aktardıkları görülmektedir. Örneğin Ö2 tarafından verilen cevap aşağıda yer almaktadır. 




Hikâyede anne fil, yavrusundan elektrik faturasını ödemesini istemektedir; ancak yavru fil faturayı yatırmak yerine gazoz ve sütlü kahve alarak çocukları mutlu etmeyi tercih etmiştir. Örnek görsel (23) öğrencilerin benzer olayları yaşadıklarına dair cümleler kurduklarını göstermektedir.

Örnek 23. 4 numaralı katıımcının verdiği cevap

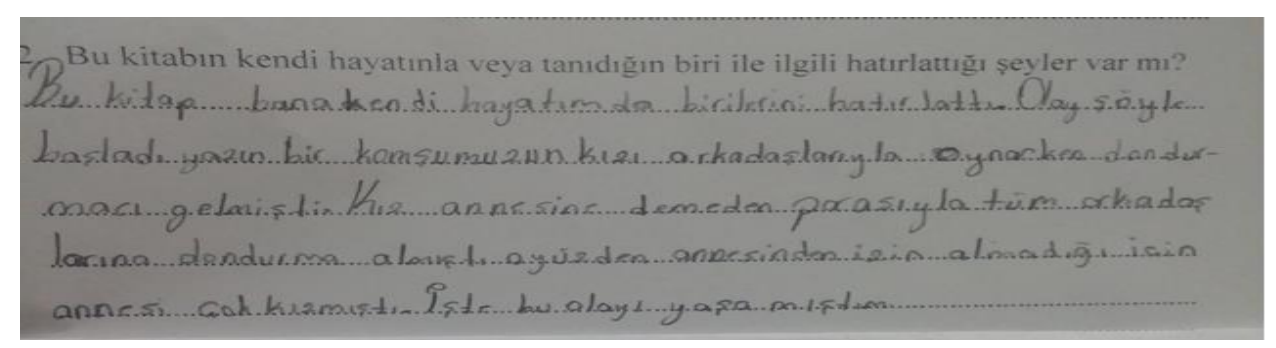

Hikâyede bir filin kendilerine gazoz dağıttığını ailelerine anlatan çocuklara, ebeveynlerinin inanmayışından söz edilmektedir.Ö61 buna benzer bir durumu deneyimlediğini belirtmektedir.

Örnek 24. 61 numaralı katıımcının verdiği cevap

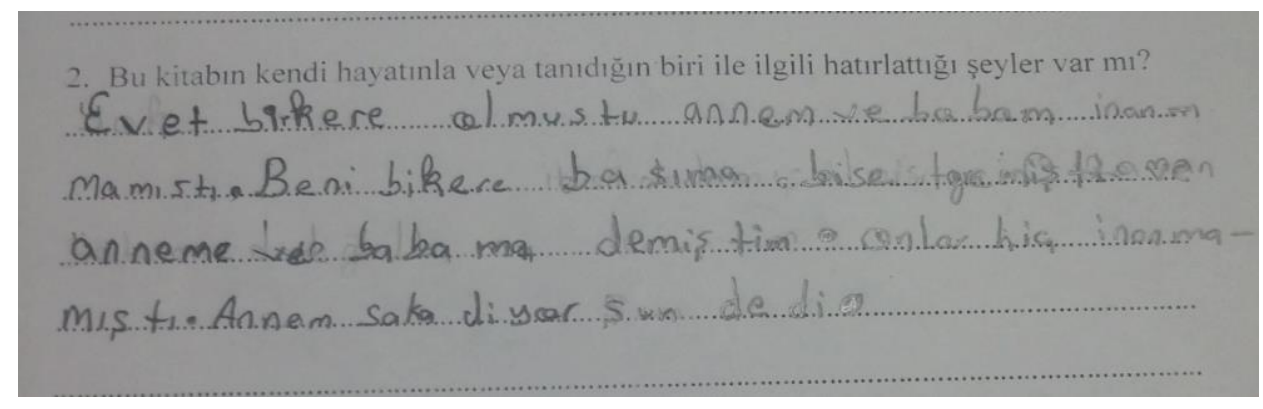

Hikâyedeki Olaylara Katılma isteğine ilişkin Bulgular

Bulgular incelendiğinde, öğrencilerin ağırlıklı olarak yavru fil olmak istedikleri ve yavru filin dağıttığı gazozu, sütlü kahveyi içen çocuk olmayı diledikleri görülmektedir. Fil olmak isteyen öğrencilerde filin yardımsever, çocuk sever, çocukları mutlu eden ve eğlendiren paylaşımcı rolünün etken olduğu görülmekteyken, gazoz ve sütlü kahve içen çocuklardan biri olmak isteyen öğrencilerde ise onların gazozu, sütlü kahveyi sevmeleri, kana kana içmek istemeleri, bu tatları diğer sevdikleriyle de paylaşmayı dilemelerinin belirleyici olduğu anlaşımaktadır.

Aşağıdaki görsele (25) göre, öğrencinin hikâyede hem yavru fil hem de gazoz ve sütlü kahve içen çocuklardan biri olmak istediği görülmektedir. 


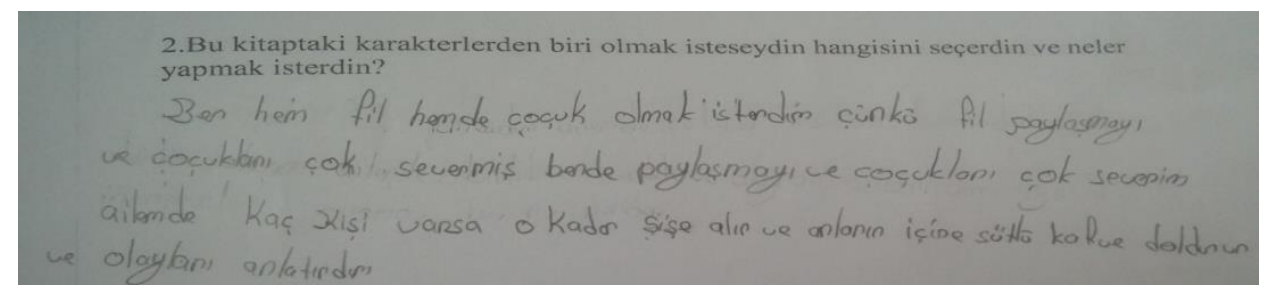

Aşağıdaki görsel incelendiğinde öğrencinin hikâyeye yönelik herhangi bir katılım göstermediği görülmektedir. Bu durum öğrencinin hikâyeyi gazoz ve sütlü kahve gibi içecekleri barındırmasıyla ilişkilendirmesinden kaynaklanmış olabilir. Ö24 tarafından verilen cevap aşağıda yer almaktadır.

Örnek 26. 24 numaralı katıımcının verdiği cevap



Tartışma, Sonuç ve Öneriler

Resimli çocuk kitaplarının ortaokul beşinci sınıf öğrencilerinde bıraktığı etki düzeyini okurtepki kuramı açısından çözümlemeye odaklanan bu çalışmada katılımcıların kitaplarda anlatılmak istenilenlerle yaşamları arasında bağlantı kurdukları, deneyimlerini yansıttıkları, kişisel duygu ve düşüncelerine yer verdikleri sonucuna ulaşılmıştır. Bu durum katılımcı öğrencilerin okur olarak kendi okumalarını ve öğrenmelerini izleme becerisi geliştirdiklerini, edebiyat metinlerini alımlama yetkinliklerini artırdıklarını gösterir (Spiegel, 1998). Nitekim Bülbül (2017) de bu tür metinlerle yürütülen uygulama çalışmalarının öğrencilerin düş gücünün, imgelem faaliyetlerinin ve özgüven duygusunun etkin olarak yeniden yapılanmasına katkıda bulunabileceği belirtmiştir.

Edebiyat yapıtı yazınsal gerçeklik karşında okuru harekete geçmeye çağııır. Bu ilişki okura etkileşimsel bir hareket alanı ortaya çıkarır. Böylece metin ile okur arasındaki etkileşimde esnek ve geniş bir özgürlük alanı meydana gelir. Bu ortamda okur açığa çıkan boşluğu çağrışımsal ve bilgisel donanımıyla ortadan kaldırarak edebiyat metninin öznel gerçekliğini inşa eder. Daha açık bir anlatımla okur belirsiz ve kaotik bir durumdan metnin yeniden üretildiği yaratıcı ve zengin bir alımlama sürecine doğru yol alır. Bu süreçte okurun rolü son derece önemlidir. Zira "okur yazınsal olgunun temel ögesidir" (Özdemir, 2017: 208). Yapılan değerlendirme sonuçlarına göre katılımcıların ağılıklı olarak okur odaklı tepkiler verdiği görülmüştür. Alanyazın incelendiğinde önceki araştırmaların buna benzer sonuçlar ortaya koyduğu görülmektedir (Pantaleo, 2007; Serafini, 2005; Ulusoy, 2016; Wollman-Bonilla ve Werchadlo, 1995; Yekeler ve Ulusoy, 2017). Bu örüntü öğrencilerin metne karşı duygu ve düşüncelerini yansıtarak anlatılanlarla öznel deneyimleri arasında ilişkiler 
kurabildiklerini, düş gücünün etkisiyle hikâyenin bir parçası olmayı istediklerini ortaya koymaktadır. Bu durum katılımcıların "başkasının düşüncelerine, bilinç içeriklerine, duyumsamalarına açılmak, başkalarının dünya ve insan anlayışıyla karşılaşmak, onlarla irdeleşmek, başkalarının ve başka olanın düşünce ve duygu dünyasında dolaşmak, böylece her bakımdan yeni boyutlar ve ufuklar kazanmak" (Kula, 2018: 338) isteğine bir kanıt oluşturabilir.

Kırmızı Kanatı Baykuş ile Gazoz Çeşmesi kitabında okurun beklenti ve deneyimlerini yansıtan okur odaklı alt boyutlara sıkça değinildiği görülmüştür. Türkyılmaz, Can ve Karadeniz (2010) gerçekleştirdikleri çalışmada Eski Edebiyat eğitiminde okur merkezli yaklaşımdan yararlanmak gerektiğini vurgulamışlardır. Türkyılmaz ve arkadaşları (2010) da çalışmalarında okurun beklenti ve deneyim ufkuyla bağlantılı bu kategorilerin en çok yararlanılan kategoriler olduğunu belirlemişlerdir. Bu nedenle iki çalışmanın bulgularının birbiriyle örtüştüğü söylenebilir.

Katılımcıların cevapları incelendiğinde karakterleri anlama kategorisinde her iki kitap için de birbirine yakın bir düzeyde cevap verildiği görülmüştür. Sever'e (2012: 76) göre "çocukların ilişki alanları çevresindekilerle sınırlıdır. Çoğunlukla anne, baba, kardeşle geçmekte olan yaşamı, kitaplardaki kahramanların serüvenleriyle çeşitlenmeye başlar." Bu yanıyla çocuk okur "her kitapta bir başka karakterle tanışır, yeni yaşantılar kazanır ve farklı deneyimler elde eder" (Karatay, 2012: 104). Buna göre öğrencilerin somut dünyayı ve onun çok yorumlu özelliğini fark etme, yeni yaşam deneyimleri keşfetme isteğinde olduklarını belirtmek mümkündür.

Yapılan bu çalışmada, yetmiş ortaokul beşinci sınıf öğrencisinin iki resimli çocuk kitabına ilişkin yazılı görüşleri alınmış ve çözümlenmiştir. Dolayısıyla çalışmanın bulguları çalışma grubu ve iki resimli çocuk kitabı ile sınırlıdır. Bu nedenle araştırmacıların daha geniş katılımlı ve daha fazla sayıda resimli çocuk kitabının kullanıldığı çalışmalar yapmaları önemlidir.

\section{Kaynaklar}

Akyol, H. (2011). Türkçe ilk okuma yazma öğretimi. Ankara: Pegem Akademi Yayınları.

Ayverdi, i. (2011). Misalli büyük Türkçe sözlük. İstanbul: Kubbealtı Neşriyat.

Bennett, A. ve Royle, N. (2004). Introduction to literature, criticism and theory, Harlow: Pearson.

Binyazar, A. (2010), Toplum ve edebiyat. İstanbul: Can Yayınları.

Bülbül, M. (2012). Bir öykü kuşağında çağ algısı ve değerler yitimi Heinrich T Böll: An der brücke. Ekev Akademi Dergisi, 50, 173-185.

Bülbül, M. (2017). Şiir türünün yabancı dil derslerinde kullanımı. Dil Dergisi, 168/2, 5-18.

Culler, J. (1981). The pursuit of signs: Semiotics, literature, deconstruction. Ithaca, NY: Cornell University Press.

Davis, T.F., ve Womack, K. (2002). Formalist criticism and reader response theory. Gordonsville, VA: Palgrave Macmillan.

Demirel, Ö. (1999). Türkçe öğretimi. Ankara: Pegem A Yayınları. 
Dilidüzgün, S. (2002). Ana çizgileriyle çocuk ve çocuk edebiyatı. Z. Güneş (Ed.), Okul öncesinde çocuk edebiyatı (ss. 37-54). Eskişehir: Anadolu Üniversitesi Yayınları.

Eagleton, T. (2008). Literary theory: An introduction: anniversary edition (Anniversary, 2nd ed.). Oxford: Blackwell Publishing.

Ekiz, T. (2007). Alımlama estetiği mi metinlerarasılık mı?,Ankara Üniversitesi Dil ve Tarih-Coğrafya Fakültesi Dergisi, 47 (2), 119 - 127.

Fish, S. (1970). Literature in the reader: Affective stylistics. New Literary History, 2, 123-162.

Galda, L. ve Beach, R. (2001). Response to literature as a cultural activity, Reading Research Quarterly, 36, 6473.

Göktürk, A. (2012). Sözün ötesi (5. Baskı). İstanbul: Yapı Kredi Yayınları.

Gönen, M. (1984). Okul öncesi çağı çocuğu ve resimli kitaplar. Okul Öncesi Eğitimi Dergisi, 16 (28), 20-21.

Holland, N. (1975). Unity identity text self. Publications of the Modern Language Association of America, 90 (5), 813-822.

Karatay, H. (2012). Çocuk edebiyatı metinlerinde bulunması gereken özellikler. T. Şimşek (Ed.), Kuramdan uygulamaya çocuk edebiyatı el kitabı (ss. 81-127). Ankara. Grafiker Yayınları.

Kavalcı, T. (2017). Üç önemli kuramcı üzerinden alımlama estetiğinin incelenmesi ve bir uygulama. SÖYLEM Filoloji Dergisi, 2 (1), 52-74.

Kula, O. B. (2008). Kant estetiği ve yazın kuramı. İstanbul: Doruk Yayımcılık.

Kula, O. B. (2012). Dil felsefesi edebiyat kuramı-II. İstanbul: İş Bankası Kültür Yayınları.

Kula, O. B. (2016). Yazınsal yapıt ve Ahmet Ümit nasıl okunabilir?. İstanbul: Everest Yayınları.

Kula, O. B. (2018). Türkiye’de aydınlanma ve Atatürk devrimleri. İstanbul: Tekin Yayınevi.

Larson, L. C. (2009). Reader response meets new literacies: Empowering readers in online learning communities. Reading Teacher, 62 (8), 638-648.

McMillan, J. H. (2004). Educational research: Fundamentals for the consumer (4th ed.). USA: Pearson Education, Inc.

MEB. (2017). Türkçe dersi öğretim programı ve kılavuzu (1-8. Sınıflar). Ankara: Millî Eğitim Bakanlığı.

Merriam, S. B. (2013). Nitel araştırma: Desen ve uygulama için bir rehber (3. Basım). Ankara: Nobel Akademik Yayıncılık.

Moran, B. (2003). Edebiyat kuramları ve eleştirileri. İstanbul: İletişim Yayınları.

Oral, F. (2016). Kırmızı kanatı baykuş (4. Baskı). İstanbul: Yapı Kredi Yayınları.

Ötgün, C. (2008). Sanat yapıtına yaklaşım biçimleri. Gazi Üniversitesi G.S.F. Sanat ve Tasarım Dergisi, 2, 159-178.

Özbek, Y. (2013). Postmodernizm ve alımlama estetiği. Konya: Çizgi Kitabevi.

Özdemir, E. (1997). Eleştirel okuma (2. Baskı). Ankara: Ümit Yayıncılık.

Özdemir, E. (2002). Dilin öte yakası. İstanbul: Yapı Kredi Yayınları.

Özdemir, E. (2017). O iyi kitaplar olmasaydı (3. Basım). Ankara: Bilgi Yayınevi.

Padley, S. (2006). Key concepts in contemporary literature. New York: Palgrave Macmillan.

Pantaleo, S. (2007). Scieszka's the Stinky Cheese Man: A tossed salad of parodic reversions. Children's Literature in Education, 38 (4), 277-295.

Parla, J. (2017). Don Kişot (yorum, bağlam, kuram) (1. Baskı ). İstanbul: İletişim Yayınları. 
Rosenblatt L. M. (1982). The literary transaction: Evocation and response. Theory into Practice, 21 (4), $268-277$.

Rosenblatt, L. M. (1978). The reader, the text, the poem: The transactional theory of literary work. Carbondale: Southern Illinois University Press.

Rosenblatt, L. M. (1983). Literature as exploration (4th ed.). New York: Modern Language Association.

Schraw, G. ve Bruning, R. (1996). Readers implicit models of reading. Reading Research Quarterly, 31, $290-305$.

Scott, L. M. (1994). The bridge from text to mind: Adapting reader-response theory to consumer research, Journal of Consumer Research, 21, 461-480.

Serafini, F. (2005). Voices in the park, voices in the classroom: Readers responding to postmodern picturebooks. Reading Research and Instruction, 44 (3), 47-64.

Sever, S. (2012). Çocuk ve edebiyat. İzmir: Tudem Yayınları.

Sever, S. (2013). Çocuk edebiyatı ve okuma kültürü. İzmir: Tudem Yayınları.

Sipe, L. R. (2008). Story time: Young children's literary understanding in the classroom. New York, NY: Teachers College Press.

Smith, M. (1992). Submission versus control in literary transactions. Inj. Many\& C. Cox (Eds.), Reader stance and literary understanding (pp. 143-161). Norwood, NJ: Ablex.

Smith, M. W. (1991). Constructing meaning from text: An analysis of ninth-grade reader responses. Journal of Educational Research, 84, 262-271.

Spiegel, D. L. (1998). Reader response approaches and the growth of readers. Language Arts, 76 (1), 41-48.

Sumara, D. (1996). Understanding reading as a focal practice. English Quarterly, 28 (1), 18-26.

Swaggerty, E. A. (2006). Is someone reading us? Fourth grade students respond to postmodern picture books. Tennessee, The University of Tennessee, Doktora Tezi.

Şimşek, Y. (2013). Fazıl Hüsnü Dağlarca'nın “Kızılırmak Kıyıları” şiirini sosyolojik okuma denemesi. Turkısh Studies, 8 (1), 2547-2562.

Türkyılmaz, M., Can, R. ve Karadeniz, A. (2010). Alımlama estetiği ve okur merkezli yaklaşımın Eski Edebiyat Eğitimine uygulanması. Selçuk Üniversitesi Ahmet Keleşoğlu Eğitim Fakültesi Dergisi, 29, 153-172.

Tyson, L. (1999). Critical theory today: A user-friendly guide. New York: Garland Publishing.

Uçan, H. (2006). Edebiyat eğitimi: Estetik bir hazzın edinimi, okumanın alışkanlığa dönüştürülmesi ve yazınsal kuramlar. Milli Eğitim Dergisi, 169, 25-39.

Ulusoy, M. (2016). Resimli çocuk kitapları ve okur-tepki teorisi. Illköğretim Online, 15 (2), 487-497.

Wollman-Bonilla, J. ve Werchadlo, B. (1995). Literature response journals in a first-grade classroom. Language Arts, 72, 562-570.

Yekeler A. D. ve Ulusoy, M. (2017). İlkokul öğrencilerinin bilgi verici resimli çocuk kitaplarına yönelik tepkileri. Anadolu Kültürel Araştırmalar Dergisi, 1 (2), 20-39.

Yıldııım, A., ve Şimşek, H. (2011). Sosyal bilimlerde nitel araştırma yöntemleri (8.Basım). Ankara: Seçkin Yayınları.

Yin, R. K. (2003). Case study research: Design and methods. (3rd ed.). Thousand Oaks: Sage Publications.

Yüce, S. (2016). Edebiyatta gerçekçilik ve alımlama estetiği. SÖYLEM Filoloji Dergisi, 1 (2), 105-117.

Zainal, Z. I., Termizi, A. A. Yahya, R. W., ve Deni, A. R. M. (2010). Advancing students' responses to literary texts through the use of literary journals. The English Teacher, 34, 222-232.

Zengin, M. İ. (2015). Gazoz çeşmesi. İstanbul: Vakvak Yayınları. 


\section{Extended Abstract \\ Introduction}

Reading can be described as "visualizing what is written in a text and the same time unrevealing it by vocalizing; ongoing, complex and an interest whose effects will occur later; voice becomes meaningful by writing" (Ayverdi, 2011: 946; Demirel, 1999: 50). In other words, reading is not only a way to understand the written form of a language, it is also a mental and intellectual act based on creating meaning through cognitive analysis and perception. In another expression "purpose of reading is to make sense of purpose" (Akyol, 2011: 1). In this context, while going through a communicative activity with the printed and written symbols, the reader is in a fuzzy discovery act in the fictional world (Bennett\&Royle, 2004; Kula, 2008; Özdemir, 1997; Rosenblatt, 1982).

A text "remains as an ink spot until the reader converts it into the meaningful symbol sequences" and the meaning in the text is completed by the reader. The reader keeps a constant connection between the text and his own real world; while discovering that reading literature does not only tell about the life, but also provides an experience to "live" (Rosenblatt, 1983: 24-38). This awareness allows the reader to feel what the author has written and to add a creative power during reading (Binyazar, 2010). Moreover, the reader can broaden or minimise the fiction universe presented to him/her. The text is a secret treasure waiting to be discovered. Uncovering and discovering this hidden phenomenon require the experience and knowledge of the reader. The reader produces the meaning in the pre-existing cultural pattern by intellectualizing his/her consciousness and sensibility. At the core of the reading, the reader's mental effort is important and that's why is prioritized. The reader is the primary object in the struggle of comprehending and interpreting the inner nature of the texts. The reader, as a tracker, internalises hidden truths of the texts with references. It can be said that the receiver takes the meaning of the text to a personal level as a result of activating it in the reading process.

Method

The study was designed to determine the feedback of the fifth-grade students of secondary school on the Kırmızı Kanatlı Baykuş which was written and illustrated by Feridun Oral and awarded as the best illustrated story book in 2012, and on the Gazoz Çeşmesi which was written by Mevlana İdris Zengin and illustrated by Dağıstan Çetinkaya. This research was designed by using case study from qualitative research method.The study was carried out in the spring term of 2016-2017 academic year with the participation of 70 students (34 females, 36 males) studying in the fifth-grade in Tokat.

\section{Result and Discussion}

Having examined Kırmızı Kanatlı Baykuş, it was figured out that the participants'feedback was more reader-focused and less text-focused. It was clear that the mostly emphasized responses were about personal questions.

When looking at the Gazoz Çeşmesi, it was determined that the participants' responses were mostly reader-focused. In contrast, text-focused responses were found to be less.

In this study which focuses on analyzing the effect level of illustrated children's book on the fifth-grade students at secondary school in terms of reader-response theory, it was found that the participants related what was told in the book with themselves and that they reflected their experiences, personal feelings and thoughts.

According to the results of the evaluations, it was seen that the written feedback of the participants was more reader-focused. This finding revealed that the students reflect their own feelings and thoughts to the text and they can relate their personal experiences with what was told in the book and they wanted to be a part of the story. It was determined that there were more reader-focused responses in research on the children's reactions to the illustrated books (Pantaleo, 2007; Serafini, 2005; Ulusoy, 2016; Wollman-Bonilla ve Werchadlo, 1995; Yekeler\&Ulusoy, 2017). 